\title{
MENGGUGAH PERILAKU TELADAN POLITISI DALAM RANGKA MEMPERSIAPKAN GENERASI MUDA BERDEMOKRASI SECARA ELEGAN
}

\author{
Prof. Dr. Made Yudana, M.Pd. \\ Program Studi PPKn \\ Jurusan Hukum dan Kewarganegaraan \\ Fakultas Hukum dan Ilmu Sosial \\ Universitas Pendidikan Ganesha Singaraja
}

\begin{abstract}
Prolog
Mengutip Nabi Besar Muhammad SAW, Eep Saefulloh Fatah (1999) menyatakan "Jihad yang paling utama adalah mengucapkan kata-kata yang benar kepada penguasa yang zalim”. Kalimat sufi bertabur kebajikan ini, barangkali sangat layak untuk kita simak dan renungkan di tengah hingar-bingar negeri menyongsong Pemilu Serentak April 2019 yang akan datang. Sebagai masyarakat, tentu kita berdoa dan bermohon kepada Tuhan, agar Presiden dan Wakil Presiden serta para wakil rakyat (DPR-DPD-DPRD) yang terpilih adalah mereka putra terbaik Bangsa yang memiliki kemampuan dan kemauan serta kapasitas untuk memimpin Indonesia di semua level ke depan dengan mempertontokan kultur politik yang elegan, hanif dan bijak, sehingga menebar lebih banyak maslahat bagi Bangsa dan Negara. Seturut dengan ekspektasi ideal tersebut, berharap agar pemimpin ke depan mampu menebar kebajikan demi maslahat orang banyak, tanpa peduli dengan proses bagaimana perhelatan pemilu serentak ini dilaksanakan, tentu tidak adil. Presiden dan Wakil Presiden serta para legislator serta senator sebagai produk tidak akan dapat memberi maslahat yang kita harapkan, jika proses pemilu yang kita gelar tidak steril dari praktik-praktik kotor, sesat dan membodohkan yang sering disebut sebagai praktik mobokrasi. Atas dasar itu, dalam konteks pemilu serentak kali ini, proses sebagai entry point harus dapat kita kontrol, demi terjadinya rivalitas yang dilandasi semangat toleransi. Perhelatan ini disamping harus melahirkan produk yang baik (para pemimpin yang legitimate dan mengabdi kepentingan rakyat), juga yang tidak kalah penting adalah mampu melahirkan sistem politik yang dinamis, dan mampu meletakkan landasan kultural yang bernas.
\end{abstract}

\section{Berkaca dari Sejarah}

Harapan ideal pada prolog di atas sejatinya bukan sesuatu imagin yang ironi dan ilusif. Sebab jika berkaca dari sejarah, bangsa ini di masa awal pemancangan tiang kedaulatan telah mempraktikkan cara-cara bernegara yang elegan. Dikeluarkannya Maklumat Wakil Presiden No. X pada Oktober 1945, dan disusul maklumat Pemerintah Nopember 1945 sebagi entry point Indonesia memasuki sistem multipartai dan eksperimen demokrasi liberal menjadi catatan tersendiri. Tanpa bermanksud membandingkan format sistem pemerintahan yang diterapkan, apakah presidentil dan atau parlementer, yang pasti bahwa pada 
episode ini berhasil dibangun perangkat kultural yang sangat penting. Pada episode ini dipertontonkan oleh para elite bangsa kultur yang bernas, yakni penghargaan atas perbedaan, kesiapan menjalani kompetisi politik secara sehat, kesiapan untuk menjalani sirkulasi kekuasaan, kesiapan menjadi pemenang yang baik dan menjadi pecundang yang terhormat, serta kesiapan membangun toleransi listaskelompok-lintasideologi dan lintaskepentingan. Disamping itu, tradisi oposisipun berkembang cukup sehat. Studi-studi tentang masa itu, sangat banyak mewartakan romantisme perpolitikan yang mengundang kekaguman. Walau pada masa itu digambarkan betapa suasana kehidupan politik ditandai pertentangan-pertentangan antar idiologi dan kelompok serta antar kepentingan, namun suasana saling toleransi antar-ideologi-kelompokkepentingan itu masih terpelihara dengan baik.

Episode yang sangat elegan ini, berlanjut terus sampai pasca Pemilu 1955. Pada periode ini, elit politik kita mulai mengalami fragmentasi secara kepartaian. Pemilu 1955 memberikan argumen sederhana bagaimana fragmentasi elite itu terbentuk. PNI, NU, Masyumi, PKI, PSI, muncul sebagai partai besar pemenang pemilu. Konstelasi ini berkonsekuensi logis pada "konstelasi perilaku" elite ketika itu. Mulai terjadi perbedaan dalam melihat segala sesuatu. Bila pada periode sebelumnya fragmentasi kepartaian terjadi belum mendapatkan legitimasi rakyat, maka di era ini para elite negeri ini seolah lebih percaya diri dengan hasil pemilu yang mereka raih. Dinamika politik elite begitu hebat. Tercatat sidang maraton dalam merumuskan konstitusi-baru menggambarkan konstelasi politik sekaligus cakrawala intelektual yang menangkupi elite politik ketika itu. Kualitas elite politik kala itu begitu mudah kita lacak dalam risalah sidang konstituante. Betapa satu sama lain, meskipun mereka berbeda pandangan, keyakinan, ide dan gagasan, tetapi perdebatan mereka tetap sesuatu abstraksi yang bernas. Bagaimana seorang Hamka menguaraikan sejarah umat Islam sebagai argumennya menjadikan Islam sebagai dasar negara di sidang konstituante, dengan rujukan studi yang bertanggungjawab. Namun dengan cekatan pula A.A Maramis membantah Hamka, dengan argumen ilmiah lain yang juga tidak kalah validitas referensinya. Lain pula dengan Natsir (Masyumi) dan IJ Kasimo (Partai Katolik) yang dapat dipastikan selalu tajam, kritikal dan intelek argumentasinya disetiap sidang parlemen, namun mereka tidak pernah absen bertukar kirim makalah untuk saling berbagi ide. Silaturahmi personal antar elite yang satu dengan elite yang lain terjalin sangat kohesif, walau secara ide dan gagasan mereka berbeda.

\section{Pemimpin, antara Dilahirkan atau Dibentuk \\ Dalam sesi kuliah} kepemimpinan yang saya asuh baik di program S2 maupun S3, acapkali mahasiswa bertanya: pemimpin itu dilahirkan atau dibentuk?. Untuk menjawab pertanyaan mahasiswa yang sudah tergolong sangat dewasa 
seperti ini, sebagai pengajar tentu saya harus menjawab dengan strategi yang cerdas, misalnya dengan mengisahkan Berandanya Arief Budi Santosa di harian Bisnis Indonesia 9 Maret 2013 bertajuk Pemimpin atau Selebritas. Mengambil pengandaian seorang penyanyi, tentu saya merangsang daya pikir mahasiswa dengan mengemukakan bahwa Penyanyi yang dibilang punya bakat kuat sejak kecil, belum tentu berhasil menjadi penyanyi tenar. Untuk menjadi tenar tidak mudah. Bukan Cuma bakat, tetapi ternyata butuh latihan, terus dan terus menerus, dengan disiplin kuat. Bahkan kerap, tidak hanya latihan, tetapi juga ikut sekolah musik dan sekolah vokal. Artinya, tidak serta merta punya bakat, atau ayah ibunya penyanyi, maka ia bisa menjadi penyanyi tenar.

\section{Contohnya Cakra Khan.}

Penyanyi dengan suara serak-serak khas yang kini lagunya kondang bernuansa "lawan kata" itu disebut berkali-kali gagal mengikuti kompetisi. Tetapi tanpa kenal lelah, ia terus berlatih, sekolah vokal, dan terus mencoba dan akhirnya berhasil meledakkan hits berjudul Harus Terpisah yang digemari banyak orang. Ringkas kata, tidak ada sukses atau hasil yang bersifat instan. Ada bibit bakat, tetapi juga disiplin latihan, dan terus menerus ditempa pengalaman. Berani mencoba, ambil risiko, dan mengambil keputusan untuk fokus pada tujuan.

Seturut dengan pengandaian tersebut, maka saya percaya, pemimpin itu tidak hanya dilahirkan tetapi dibentuk. Dan tidak Cuma dibentuk, pemimpin perlu punya resep sendiri. Seseorang layak memperoleh "gelar" sebagai pemimpin jika ia taat menjaga tujuan, menjaga proses, dan menjaga manusia.

Menjaga tujuan berarti memiliki visi dan mampu menerapkan berbagai upaya untuk mencapai visinya tersebut. Seorang pemimpin visioner dapat menangkap perhatian setiap insan dalam organisasi yang merupakan salah satu unsur terpenting dari kepemimpinan. Pribadi seperti itu memancarkan pemikiran tunggal tingkat tinggi dan dedikasi terhadap suatu visi atau cetak biru masa depan. Pemilikan visi ini membedakan pemimpin yang berbakat dari mereka yang kurang berbakat. Pemimpin yang memiliki visi, tidak akan pernah kehilangan visi objektif jangka panjangnya sementara masih menangani kesempatan dalam jangka pendek atau kemunduran dalam lingkungan yang selalu berubah. Fakta paling anyar yang dapat diangkat sebagai contoh untuk masalah ini adalah usaha Walter Wriston yang berhasil melihat betapa pentingnya menempatkan Citibank untuk menjadi pemimpin dalam teknologi perbankan di awal 80an.

Ia menyadari bahwa ia harus membuat Citibank menjadi pesaing agresif dalam sektor jasa finansial yang dideregulasi dan selalu berubah, terutama dalam bagian perbankan pengecer. Begitu pula Roger Smith yang menjadi CEO dari General Motors, sudah melihat perlunya mengubah GMusaha industri terbesar di duniauntuk lebih luwes dan inovatif daripada sebelumnya. Ia sadar bahwa organisasi harus bersiap lebih baik untuk menghadapi tantangan 
berkelanjutan terutama dari pabrikan pembuat mobil jepang.

Baik Wriston maupun Smith sudah membuat persepsi kebutuhan untuk berubah. Mereka memiliki visi jelas ke arah mana organisasi mereka harus berjalan, mengomunikasikan visi itu, menciptakan komitmen di seluruh lapisan organisasi dan memberlakukan perubahan yang diperlukan.

Menjaga proses maknanya adalah memiliki cara yang tepat untuk mencapai visi-misi. Pemimpin organisasi yang menganut seperangkat nilai dasar deferensiasi, dan selalu menekankan nilai itu dalam pidato, bahan tertulis dan dalam rapat dengan pegawai, menumbuhkan dinamika dalam organisasi. Nilai itu dapat juga menjadi kerangka untuk membantu para decision maker mengambil keputusan, jika umpamanya, produk dan pelayanan kepada pelanggan merupakan prioritas tinggi sebagaimana direkomendasikan oleh Daft (2004) dengan dalil Produce Good and Service Efficiently, maka sudah sepantasnya involve customers in the business process, adalah suatu strategi yang bijak. Wangsit cerdas ini menuntun kita untuk mampu mendesain dan menciptakan produk yang presisi, dengan konsep melibatkan pelanggan. Strategi melibatkan pelanggan kini dan ke depan sangat prinsip, karena menurut Seybold dalam Perama (2004) kesuksesan mendesain produk yang presisi bermula dari "develop a deep understanding of how the customers do their job and help them to do it".
Prinsip ketiga, menjaga manusia mengandung pengertian yang mendalam. Tidak sulit untuk dipahami bahwa karena karakter uniknya, manusia telah diyakini sebagai resources yang paling penting dalam semua level dan jenis organisasi. Keutamaan dan keunikan manusialah yang juga menginspirasi para kampiun manajemen memekarkan fungsi organisasi dari yang semula tiga (planningorganizing-controling) menjadi lima (planning-organizing-actuatingleading\&influensing-controling).

Kaitan dengan sumber daya manusia, prinsip penting dan utama yang harus di pegang adalah ngewongke uwong, sebuah falsafah kuno jawa yang memiliki kandungan bijak yakni orientasi humanis. Di era Venus sekarang ini, Woman need empathy, not solution, kata John Gray dalam (Kartajaya, 2004). Penduduk Venus menilai lebih tinggi empati ketimbang solusi. Ia lebih menghargai perhatian kita ketimbang solusinya. Ia lebih menghargai contex-nya, ketimbang content-nya. Sepertinya tidak logis, tapi itulah emosi. Di Venus emosi sering kali "menawan" rasio kita saat kita mengambil keputusan. Di Venus yang sangat emosional, peran empati menjadi kian penting untuk mewujudkan customer experience. Dalam konteks kepemimpinan politik, barangkali kita layak merenungkan esensi pamong praja sebagai pagangan bagi para pemimpin dalam melaksanakan kepemimpinannya.

Selaras dengan sisi-sisi akademik kepemimpinan tersebut, maka kalau pemimpin terlalu banyak tanya kiri-kanan tetapi tidak 
mengambil keputusan, maka ia sebenarnya cuma koordinator, bukan leader. Pemimpin harus berani mengambil risiko untuk membuat keputusan dan karenanya tidak bisa menyenangkan semua orang yang dipimpinnya. Yang penting, risiko dihitung demi manfaat yang lebih besar. Dan kalau keputusan pemimpin membuatnya memperoleh citra yang baik, itu adalah dampak sebagai pemimpin yang mengambil keputusan dengan benar. "Lantas bagaimana kalau pemimpin lebih banyak pencitraan saja?" Itu pertanyaan Bupati Jombang Suyanto kepada Pak Jusuf Kala (Pak JK), dalam sebuah acara rekaman program acara Jalan Keluar untuk Kompas TV, beberapa waktu silam. "Kalau itu bukan pemimpin, tetapi selebritas," Ujar Pak JK, yang membuat semua orang tergelak dan terbahak. Bagaimana menurut anda?

\section{Penutup}

Duapuluh tahun perjalanan reformasi, sebuah tatanan yang kita niatkan dapat melecut kemajuan negeri, ternyata berbuah ironi. Disparitas antara pemimpin ideal yang kita dambakan dengan fakta kepemimpinan yang dipertontonkan oleh elite bangsa saat ini memang sangat senjang. Dalam negara bangsa yang menganut sistem paternalistik dengan niatan agar tauladan mengalir dari atas, dan berharap contoh datang dari para pemimpin ternyata malah ilusi, karena faktanya para para elite kita lebih suka mempertontonkan kultur barbarfurbaisme yang bertolak belakang dari ciri komunitas masyarakat beradab. Alkisah negeri ini miskin pemimpin dan kaya penguasa.
Patut dijadikan renungan, apa yang salah dari negeri ini? Adakah proses rekruting calon pemimpin yang belakangan ini (sejak reforamsi) kita serahkan sepenuhnya kepada partai politik menjadi akar penyebab distorsi semacam ini? Adakah kecendrungan munculnya praktik pangreh-praja dalam kultur tatapraja kita merupakan pertanda gagalnya kita sebagai bangsa memahami secara baik dan benar esensi pamong-praja yang adiluhung? Adakah anomali sejarah yang minimpa negeri pertanda gagalnya kita memahami sejarah secara utuh dan holistik? Semua anomali ini sangat layak kita renungkan bersama, sebab sebagai bangsa kita seharusnya bukan keledai, terantuk duakali di tiang yang sama.

\section{Daftar Referensi}

Daft, R. L. 2004. Organization Theory and Design. USA: Vanderbilt University.

Drake, R. L. 1985 Leadership: It's a Rare Blend of Traits. New York: American Management Association.

Goleman, D, et al. 2005. Primal Leadership: Kepemimpinan Berdasarkan Kecerdasan Emosi. Edisi Indonesia. Jakarta: Gramedia.

Hesselbein, Goldsmith, Beckhard. 1997. The Organization of the Future, San Fransisco : Jossey Bush Publishers.

Kartajaya, H. 2004. Marketing In Venus. Jakarta: Gramedia Pustka Utama.

Katz, D. \& Kahn R. L. 1976. System Rewards and Individual Rewads: A Contingency 
Jurnal Media Komunikasi Pendidikan Pancasila dan Kewarganegaraan

Volume 2, Nomor 1 April 2020

Approach. Chicago: St. Clair Press.

Kennedy, D. L. 1984. Understanding Personal Power. New York. American Management Association.

Perama, G. 1996. Praktek Kepemimpinan Berdasarkan
Air, Refleksi Kepemimpinan Bisnis. Jakarta: Gramedia Timpe, A. D. 1991a. Memimpin Manusia, Seri Ilmu dan Seni Manajemen Bisnis. (Edisi Bahasa Indonesia) Jakarta : Gramedia. 